\title{
Weak mineralization despite strong processing of dissolved organic matter in Eastern Arctic tundra ponds
}

${ }^{1}$ Centre for Northern Studies and Centre Eau Terre Environnement, Institut National de la Recherche Scientifique, Quebec City,

Quebec, Canada

$12{ }^{2}$ Takuvik and Laval University, Quebec City, Quebec, Canada

$13{ }^{3}$ Department of Planning, Infrastructure and Environment, New South Wale Government, Parramatta, New South Wales, 4 Australia

${ }^{4}$ Department of Civil, Construction, and Environmental Engineering, San Diego State University, San Diego, California

16

Seasonal thawing of surficial permafrost is associated with waterlogging on many tundra landscapes (Grosse et al. 2013). The accelerated warming of the Arctic intensifies soil erosion and subsidence in ice-rich areas and the transfer of terrestrial carbon (C) and nitrogen to aquatic systems (Schuur et al. 2015; Vonk et al. 2015; Wauthy et al. 2018). In addition, climate warming lengthens the ice-free season (Surdu et al. 2016), which further contributes to the warming of surface waters

*Correspondence: isabelle.laurion@inrs.ca

Additional Supporting Information may be found in the online version of this article.

Limnology and Oceanography, Special issue Arctic aquatic ecosystems in the $21^{\text {st }}$ century

51 Author Contribution Statement: I.L. designed and performed the 52 experiments, and wrote the paper with a substantial contribution from all co-authors. K.N. performed the experiments and analyzed DOM samples.

53 P.M. and N.M. analyzed data including PARAFAC component extraction 54 and graph design. F.M. helped in reviewing the literature.
(O'Reilly et al. 2015) and the increased exposure of water bodies to solar radiation (Williamson et al. 2014). The vast organic C pool locked in permafrost-affected soils (estimated at $\sim 1300 \mathrm{Pg}$, Hugelius et al. 2014) is now partly mobilized to the hydrosphere in the form of dissolved organic matter (DOM) as permafrost thaws. The combination of warming and longer periods of solar exposure has the potential to accelerate the mineralization of this $\mathrm{C}$. There is not yet a consensus on the importance of ancient $\mathrm{C}$ mineralization in disrupting the global C cycle (Gao et al. 2013; Drake et al. 2015; Comyn-Platt et al. 2018; Elder et al. 2018; Knoblauch et al. 2018; Bogard et al. 2019). However, recent estimations suggest that thawing could release to aquatic systems $\sim 15 \%$ of the soil C currently stored in permafrost regions over the next $300 \mathrm{yr}$ under a business-as-usual warming scenario (McGuire et al. 2018). The fate of this $\mathrm{C}$ pool needs to be evaluated since even a partial transfer to the atmosphere could result in a positive feedback onto climate warming (Turetsky et al. 2020). Tundra lakes and ponds may be a critical element of this transfer where 
1 conditions favor $\mathrm{C}$ mineralization, particularly as they are 2 increasing in importance in many regions of the Arctic (Lara 3 et al. 2015; Liljedahl et al. 2016; Martin et al. 2017).

In surface waters, DOM is concurrently exposed to photochemical and biological degradation (Obernosterer and Benner 2004), two processes that contribute to the release of greenhouse gases (GHG) into the atmosphere. The relative

8 contribution of these processes to the overall $\mathrm{C}$ budget of a

9 lake depends on sunlight availability, water residence time,

10 mixing regime, and the intrinsic properties of DOM (Lapierre

11 and del Giorgio 2014; Cory and Kling 2018). As shown

12 through quantum yield determinations (Groeneveld et al. 2016

13 and references therein), ultraviolet radiation (UVR) is most

14 efficient at transforming and mineralizing DOM, but is

15 quickly attenuated in the water column of colored lakes.

16 While only surface waters are exposed to significant radiation,

17 depending on the mixing regime, this layer can be renewed

18 on a daily cycle (Forrest et al. 2008), increasing the efficiency 9 of $\mathrm{C}$ cycling through photobleaching.

Many studies have underscored how sunlight can efficiently degrade DOM since the 1970s (Strome and Miller 1978), although this effect is not always measured in C cycle investigations. Photochemical oxidation of DOM is considered an important removal mechanism of terrestrial DOM in Arctic freshwaters (Cory et al. 2014). It occurs through two 6 pathways: direct abiotic production of $\mathrm{CO}_{2}$ through complete photooxidation of DOM, and indirect production of $\mathrm{CO}_{2}$ 8 through microbial respiration of smaller and more bioavailable photoproducts (Vähätalo et al. 2003; Cory and 30 Kling 2018). To explore the synergistic effects of biotic and abiotic pathways, microbial and photochemical DOM decay need to be assessed concurrently.

Microbial respiration of allochthonous DOM is considered 4 as the main driver of lake $\mathrm{CO}_{2}$ supersaturation. However, because chemical and optical characteristics of DOM and the 36 underwater light field are complex and variable across land37 scapes, the contribution of photodegradation to freshwater

$38 \mathrm{CO}_{2}$ production is not well constrained. According to a global

39 upscaling exercise for lakes and reservoirs worldwide, but

40 based on results obtained on Swedish lakes, only about one-

41 tenth of freshwater $\mathrm{CO}_{2}$ emissions would originate from direct

42 photomineralization (Koehler et al. 2014). On the other hand,

43 the importance of photomineralization was shown to vary

44 seasonally, reaching $49 \%$ of the total pelagic $\mathrm{CO}_{2}$ production

45 after ice melt for a boreal lake (Vachon et al. 2016). With

46 ongoing climate change affecting many physical features of

47 lakes including ice-cover duration, water residence time and

48 mixing regimes, the accelerated decay of DOM caused by sun-

49 light appears as a fundamental factor to consider in $\mathrm{C}$ cycling

50 assessments (Wrona et al. 2016).

51 The few studies addressing DOM degradation in permafrost 52 regions present fairly contrasting results. For example, ancient 53 DOM from Yedoma permafrost thaw streams was shown to be 54 highly biolabile (Vonk et al. 2013; Abbott et al. 2014; Drake et al. 2015; Mann et al. 2015). Moreover, studies of waters of 55 the North Slope of Alaska near Toolik (syngenetic permafrost 56 with variable organic and ice contents) indicated that DOM was highly susceptible both to direct and indirect photomineralization (Cory et al. 2013), with photooxidation suggested as the dominant oxidation process in Arctic freshwaters (Cory et al. 2014). On the other hand, no $\mathrm{CO}_{2}$ was produced directly out of photodegradation, at least in the Kolyma River basin (Stubbins et al. 2017). Furthermore, incubations of High Arctic pond DOM to sunlight also revealed the absence of significant loss in dissolved organic carbon (DOC) over a few days, but a rapid loss of color and the cleavage of large molecules into smaller moieties (Laurion and Mladenov 2013). Humic waters from frozen peat bogs in Siberia were shown to be resistant to both photochemical and microbial mineralization (Shirokova et al. 2019), and low biolability of permafrost soil organic matter has been recently reported (Kuhry et al. 2020). Much still remains to be understood regarding the combined effects of microbial and sunlight degradation processes on DOM mineralization in Arctic freshwaters.

The oyerarching objective of this study was to assess if pelagic DOM processing contributes to $\mathrm{CO}_{2}$ production in Canadian Arctic ponds with variable origins (topographic and thermokarstic). Ponds are an abundant component of the polygonal tundra landscapes and large GHG emitters in summer (Bouchard et al. 2015). They receive inputs of organic matter from surrounding peaty soils as well as from benthic and littoral primary producers thriving in these shallow systems, which are exposed to sunlight for about 3 months per year. Using field experiments to concurrently quantify the biodegradation and photodegradation of DOM under natural conditions, we tested the hypothesis that sunlight accelerates DOM mineralization in tundra ponds of a non-Yedoma region, particularly in trough ponds that are impacted by permafrost subsidence and erosion. This study contributes to the understanding of Arctic DOM degradability, focusing on an overlooked geographical area.

\section{Methods}

\section{Study site and selected ponds}

The studied ponds are located in a glacier valley of Sirmilik National Park on Bylot Island, Nunavut, Canada $\left(73^{\circ} \mathrm{N}\right.$, $\left.80^{\circ} \mathrm{W}\right)$, in a region of continuous syngenetic permafrost cryoturbated by the formation and decay of ice wedges. Although this site is not located within regions where the largest $\mathrm{C}$ stocks were identified for the frozen north (Hugelius et al. 2014), the studied valley represents many other circumpolar, polygonal landscapes that contain vast stocks of $\mathrm{C}$, including the Lena Delta (Abnizova et al. 2012) and the Barrow Peninsula (Lara et al. 2015). Soils are composed of alternating peat and wind-blown sand and silt materials, which started to accumulate over glaciofluvial sands and gravels around 3700 years ago (Fortier and Allard 2004). These 83 57 58 59 60 61 62 63 64 65 66 67 68 69 70 71 72 73 74 75 76 77 78 79 80 81 82 84 85 86 87 88 89 90 
1 deposits contain excess pore ice, and their gravimetric organic 2 matter content can reach over $50 \%$, with an active layer depth 3 generally ranging between 40 and $60 \mathrm{~cm}$ (D. Fortier, pers. 4 comm.). Sedges, grasses, brown mosses, and cyanobacterial mats dominate primary production in this area.

We selected four ponds to cover the range of morphological and limnological conditions found on this type of landscape (Table 1). Two ponds classified as polygonal ponds (BYL1

9 and BYL22) are lying over low-center polygons. BYL1 is a coa10 lescent polygonal pond formed by pond expansion through 11 thermoerosion and wave action, connecting several polygonal 12 and trough ponds into one system, while BYL22 is a water 13 body in the depression of one low-center peat polygon, with a 14 much smaller volume, and which has already progressed to 15 merge two polygons since 2010. The two others, classified as 16 trough ponds (BYL24 and BYL38), are elongated water channels

17 formed in collapsed ice-wedge troughs. Trough pond BYL38 is

18 located on the side of a hill and highly influenced by

19 thermoerosional processes of melting snowbanks and has

20 quickly evolved and enlarged since 2010, while BYL24 (also

21 influenced by thermoerosion but with a smaller drainage area)

22 is relatively stabilized and colonized by graminoids and brown

23 mosses. Because of these differences, the four ponds selected are characterized by DOM of differing optical properties even 5.5 though they are close to each other (Table 1). Since the ponds 56 are not connected via a hydrologic network, it is assumed that 57 pond DOM takes its source from the immediate vicinity, 58 including from living terrestrial and aquatic plants, and 59 organic matter of the active layer and eroding permafrost. 60 Although the proportion of these sources has not been deter- 61 mined in the studied ponds, Fortier and Allard (2004) have 62 shown for this specific site the upward displacement of deeper 63 (older) sedimentary strata along the ice wedges, which then 64 get exposed to surface thawing. Field observations also indi- 65 cate active erosion on the shores of pond BYL38. Therefore, 66 we assume eroding trough ponds have a higher potential to receive older $\mathrm{C}$ on this landscape.

\section{Environmental and limnological conditions}

Incident photosynthetically available radiation (PAR) at the water surface and air temperature were recorded by a nearby meteorological station (CEN 2018) during the experiments (all ponds located within $1 \mathrm{~km}$ distance of the station). The incident spectrum for a typical sunny day at this latitude and dates was also obtained from Sequoia Scientific Inc. (Hydrolight software). A chain of temperature loggers (Onset

Table 1. Morphological and limnological properties of the four studied ponds in 2010 (surface water initial conditions), including pond area, maximal depth, total phosphorus (TP), soluble reactive phosphorus (SRP), total nitrogen (TN), nitrate $\left(\mathrm{NO}_{3}\right)$, chlorophyll $a$ as an index of planktonic biomass ( $\mathrm{Chl} a$ ), total suspended solids (TSS), total dissolved iron (Fe), dissolved organic carbon (DOC), DOM absorption coefficient at $320 \mathrm{~nm}\left(a_{320}\right)$, absorption slope at $285 \mathrm{~nm}\left(S_{285}\right)$, SUVA index, and biological index of fluorescent DOM (BIX). Median values for near-by polygonal and trough ponds sampled in 2009 are added for comparison.

30

32

33 Pond type

34

3

Area $\left(\mathrm{m}^{2}\right)$

36 Volume $\left(\mathrm{m}^{3}\right)$

TP $\left(\mu \mathrm{g} \mathrm{P} \mathrm{L}^{-1}\right)$

$\operatorname{SRP}\left(\mu \mathrm{g} \mathrm{P} \mathrm{L}^{-1}\right.$

$\mathrm{TN}\left(\mathrm{mg} \mathrm{N} \mathrm{L}^{-1}\right)$

$\mathrm{NO}_{3}\left(\mathrm{mg} \mathrm{N} \mathrm{L}^{-1}\right)$

Chla $\left(\mu \mathrm{g} \mathrm{L}^{-1}\right)$

TSS $\left(\mathrm{mg} \mathrm{L}^{-1}\right)$

$\mathrm{Fe}\left(\mathrm{mg} \mathrm{L}^{-1}\right)$

DOC $\left(\mathrm{mg} \mathrm{L}^{-1}\right)$

$a_{320}\left(\mathrm{~m}^{-1}\right)$

$\mathrm{S}_{285}\left(\mathrm{~nm}^{-1}\right)$

SUVA $(L \mathrm{mg}$

$\left.\mathrm{DOC}^{-1} \mathrm{~m}^{-1}\right)$

9 BIX

Date sampled

52 na, not available.

*Depth may have changed during the summer according to meteorological conditions but was measured only once.

†olume estimated from the area and average pond depth, while the precise bathymetry was available for BYL24.

*Values in parentheses correspond to SUVA values corrected after Poulin et al. (2014) for Fe concentration.

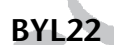

BYL24

Stabilized trough

Coalescent polygonal

Low-centered polygonal

0.8

428

$165^{\dagger}$

18.6

0.5

0.51

0.07$$
\begin{aligned}
& 0.6 \\
& 1.3
\end{aligned}
$$

0.45

8.9

13.2

0.0188

$1.8(1.5)$

0.70

10 July

\subsection{1}

11 July

1.0

88

38

38.0

1.6

0.41

0.12

1.0

5.8

1.32

7.9

36.3

0.0125

4.3 (3.2)

0.46

11 July

0

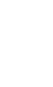

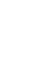

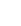

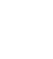

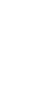

$5.4(3.6)$


Table 2. Description of the incubation treatments.

$\begin{array}{llccc}2 & \text { Color } & \begin{array}{c}\text { Treatment } \\ \text { code }\end{array} & \begin{array}{c}\text { Filtration } \\ \text { step }\end{array} & \begin{array}{c}\text { Sunlight } \\ \text { exposure }\end{array} \\ 4 & \text { code } & \text { C } & 0.2 \mu \mathrm{m} & \text { No } \\ 5 & & \text { N } & \text { No } & \text { No } \\ 6 & & \text { S } & 0.2 \mu \mathrm{m} & \text { Yes } \\ 7 & \text { BS } & \text { No } & \text { Yes } \\ 8 & & & & \end{array}$

10

11

StowAway TidbiT; accuracy $0.4^{\circ} \mathrm{C}$, resolution $0.3^{\circ} \mathrm{C}$ ) was installed in BYL1 and BYL38 at 0, 10, 20, 40, 60 and $80 \mathrm{~cm}$ depth to follow the thermal structure along the experiments, in addition to loggers placed in the incubation setting (one pair of loggers per pond in dark and light treatments for BYL1 and BYL38). Basic limnological properties of the ponds, including pond morphology, nutrients, phytoplanktonic biomass, suspended solids, and iron concentration, were measured as described in Laurion et al. (2010) and Negandhi et al. (2014).

\section{Water incubation}

The effect of sunlight and microbes on DOM degradation was tested using a three-way factorial design. The microbial assemblage responsible for DOM degradation could include Archaea and small protozoans, although the settings used for cell counts by flow cytometry likely only included the population of bacteria. Therefore, the term "bacteria" is used below for simplicity. The contrasting optical properties of the four ponds were used to test the effect of intrinsic DOM properties 2 on degradation rates concomitant with effects by differing 3 spectral exposure, as water from each pond was incubated under its respective environmental conditions. The water was collected on 10 July (BYL1), 11 July (BYL24 and BYL38), and 12 July 2010 (BYL22). The in situ incubations lasted $12 \mathrm{~d}$, with subsampling on Days 4, 7, and 12 (the exact sampling time varied among ponds).

Four treatments were applied: (1) Control (C) obtained by 40 filtering water through $0.2 \mu \mathrm{m}$ (prerinsed cellulose acetate fil41 ters, Advantec Microfiltration Systems) incubated in the dark; 42 (2) Bacteria (B) obtained on unfiltered water incubated in the 43 dark; (3) Sunlight (S) obtained using the same filtered water but 44 incubated under natural sunlight conditions; (4) Sunlight and

45 Bacteria (SB) obtained on unfiltered water incubated under th6 natural light conditions (Table 2). In the SB treatment, DOM 47 microbial degradation was not consecutive to sunlight expo48 sure but rather represents the concomitant biodegradation 49 and photodegradation in the presence of potentially 50 deleterious UVR.

51 Water was incubated in $60-\mathrm{mL}$ Teflon (sunlight) or glass 52 (dark) bottles. Teflon bottles are known for their transparency 53 to UVR despite the diffusive property of this material. A total 54 of 36 bottles were incubated in each pond, allowing the collection of three replicate bottles per treatment per sampling day. Dark was achieved using black bags covered with reflective tape and filled with ambient water to minimize temperature differences among treatments. The temperature loggers were deployed besides sunlight and dark treatment bottles of BYL1 and BYL38 to measure any discrepancies in water temperature. Bottles were floating at about $5 \mathrm{~cm}$ below the water surface (see Laurion and Mladenov 2013 for light exposure calculations at this depth for a typical summer day at this latitude). At each sampling day, the three replicate bottles were brought back to the camp where samples were treated to measure the bacterial abundance and DOM properties.

\section{DOM properties}

For DOM characterization, water was filtered (or refiltered in the case of Control and Sunlight treatments) using a syringe and capsule filter (prerinsed $0.2 \mu \mathrm{m}$ cellulose acetate) and stored in $40-\mathrm{mL}$ glass bottles in the dark at $4^{\circ} \mathrm{C}$ until spectrally analyzed back in the laboratory (within 4 weeks after the end of the experiment). The chromophoric and fluorescent fractions of DOM (CDOM, FDOM) and the DOC were analyzed from the same bottle. After optical analyses were performed, the remaining water was acidified for DOC analyses. Therefore, any changes potentially occurring in the DOM composition between the end of experiment and the completion of analyses would be consistent among results. DOC concentrations were measured using a Shimadzu TOC-VCPH carbon analyzer calibrated with potassium biphthalate standards. To characterize CDOM, absorbance scans were performed between 200 and $800 \mathrm{~nm}$ on a dual-beam spectrophotometer (Varian Cary 300) at a speed of $240 \mathrm{~nm} \mathrm{~min}^{-1}$ and a slit width of $2 \mathrm{~nm}$. Spectroscopic measurements were always run at natural $\mathrm{pH}$ and at room temperature using $1-\mathrm{cm}$ path length quartz cuvettes. Spectra were null-point adjusted (the average absorbance between 790 and $800 \mathrm{~nm}$ was subtracted from the whole spectrum). The absorption coefficient at $320 \mathrm{~nm}\left(a_{\mathrm{CDOM}}(320)\right.$, shortened to $a_{320}$ ) was used as a quantitative proxy of CDOM. The spectral slope curves $S_{\lambda}$ were obtained according to Loiselle et al. (2009) with a wavelength interval size of $20 \mathrm{~nm}$. The slope at $285 \mathrm{~nm}\left(S_{285}\right.$; calculated from 275 to $\left.295 \mathrm{~nm}\right)$ was selected as a responsive qualitative proxy on CDOM. The specific ultraviolet absorbance (SUVA) index (absorbance at $254 \mathrm{~nm}$ per unit DOC) was also calculated. The SUVA index corrected for Fe concentration according to Poulin et al. (2014) is presented in Table 1 (in parentheses).

Fluorescence properties of DOM (FDOM) were further characterized by excitation-emission matrices (EEMs) and the components extracted with PARAFAC (Murphy et al. 2013). EEM fluorescence was innerfilter-corrected, blank-subtracted, and Raman-normalized. A five-component model (C1-C5) was validated on the present data set that also included a series of EEMs originating from 33 aquatic systems located at the same site (including one creek, one kettle lake, one thermokarst lake, 20 trough ponds and 11 polygonal ponds,

\section{5} 56 57 58 59 60 61 62 63 64 65 71 72 73 74 75 76 77 78 79 80 81 82 83 84 85 86 87 88 89 90 91 92 93 94 95 96 97 98 99 
1 some sampled a few times over 2 years), to further increase 2 the sensitivity of the model. PARAFAC modeling was per3 formed according to Stedmon and Bro (2008) using the 4 Matlab drEEM toolbox (Murphy et al. 2013). Before modeling, 5 Rayleigh scatter bands were excised (first order at each wave6 length pair where excitation $=$ emission \pm bandwidth; second 7 order at each wavelength pair where emission $=2 \times$ excitation $8 \pm[2 \times$ bandwidth]). The model was validated using split-half

9 validation and random initialization. Maximum fluorescence 10 values $\left(F_{\max }\right)$ are given for each component and summed to 11 total fluorescence $\left(F_{\text {tot }}\right)$. The biological index (BIX; Huguet 12 et al. 2009) was also calculated as an indicator of the relative 13 contribution of autochthonous DOM.

14

\section{Bacterial abundance}

Water samples for bacterial abundance $(4 \mathrm{~mL})$ were fixed with a filtered solution of paraformaldehyde (1\% final concen8 tration) and glutaraldehyde ( $0.1 \%$ final concentration) after 9 adding a protease inhibitor (phenylmethanesulfonylfluoride 20 at a final concentration of $1 \mu \mathrm{mol} \mathrm{L}^{-1}$ ), and kept frozen until 21 analysis (at $-20^{\circ} \mathrm{C}$ in the field and $-80^{\circ} \mathrm{C}$ back in the laboratory). Bacterial cells were counted by flow cytometry (FACSCalibur, Becton-Dickinson). A solution of $0.94-\mu \mathrm{m}$ fluorescent beads (Polysciences) calibrated with trueCOUNT beads 5 (Becton-Dickinson) was added to each sample as an internal 6 standard to estimate cell abundance. Bacteria were labeled with SYBR green I (Sigma-Aldrich) and counted for $2 \mathrm{~min}$ at a low flow rate $\left(12-15 \mu \mathrm{L} \mathrm{s}^{-1}\right)$.

29

\section{Statistical analysis}

31 The comparison among treatments was done for all DOM 32 descriptors and the bacterial abundance, in each pond sepa33 rately, using a two-way ANOVA with time (three levels, con34 sidered as fixed) and treatment (four levels, fixed). We 35 preferred not to perform a repeated measures ANOVA as 36 experimental conditions in ponds varied with time (experi37 ments were not synchronized). Normality and homogeneity 38 assumptions were checked by graphical examination of the 39 residuals. Among the 40 variables tested (10 descriptors $\times 4$ 40 ponds), seven could not be transformed to achieve these 41 assumptions (C5 in BYL1; DOC and C5 in BYL24; $a_{320}, S_{285}$, 42 C2, and C3 in BYL38), for which we ran the Kruskal-Wallis 43 test, but results were very similar as for the ANOVA. When a 44 factor was significant, comparison of means among treatment (15.5 levels was done using Tukey HSD posthoc tests (or Tukey46 Kramer for the above-mentioned variables). Planned contrasts trit were also used to compare absorption loss (see Table 4), and 48 bacterial growth (S vs. C, or B vs. BS). To explore the changing 49 patterns of DOM under the different treatments, principal 50 component analyses (PCAs) were applied on all DOM descrip51 tors available (DOC, $a_{320}, S_{285}$, peak fluorescence $F_{\max }$ of C1 to $52 \mathrm{C} 5$, the sum of the five component $F_{\text {tot, }}$ and biological index, 53 BIX) for each pond separately. The data were centered and 54 scaled to unit variance (excluding initial conditions presented in Table 1). All univariate analyses were done using with JMP Pro v.14, the PCAs were done using the prcomp() function from $\mathrm{R}$, and we used a significance level of $\alpha=0.05$ for all statistical analyses.

\section{Results}

\section{Pond characteristics}

The limnological characteristics of the studied ponds are representative of the hundreds of polygonal and trough ponds observed at the study site (Laurion et al. 2010). The limnological characteristics of 11 polygonal ponds and 20 trough ponds sampled in the same area in 2009 are presented in Table 1 for comparison. In general, trough ponds have more nutrients (TP, SRP, TN), DOM (DOC, $a_{320}$ ) and iron (Fe), and their DOM was more colored (SUVA; see also section below for detailed comparisons of DOM properties) as compared to polygonal ponds. The colored waters of trough ponds sitting on ice wedges promote highly stratified conditions throughout the short summer, even though these water bodies are generally less than $1 \mathrm{~m}$ deep. Partial mixing events are only occurring during windy and cloudy days or at nights in trough ponds, while coalescent polygonal ponds consistently have a wellmixed water column; typical temperature profiles in coalescent pond BYL1 and trough pond BYL38 in the afternoon of a sunny and calm day and of a cloudy and windy day are shown in Fig. 1. Mixing rarely occurred below $0.6 \mathrm{~m}$ in BYL38 and did not always occur at night, with the bottom temperature remaining below $4^{\circ} \mathrm{C}$ (on average $1.1^{\circ} \mathrm{C}$ during the sampling period as trough ponds lie over ice wedges). Low-center polygonal ponds, such as BYL22, are very shallow (ca. $<30 \mathrm{~cm}$ deep) and assumed to be well mixed as they are not wedged into the topography, such as trough ponds, although their thermal structure has not been assessed.

\section{Environmental conditions during the experiment}

Weather conditions during the experiment were variable, with different combinations of sunny or cloudy days and with periods of calm or high winds (Fig. 2). Incoming PAR varied between $8 \mu \mathrm{mol}$ photons $\mathrm{m}^{-2} \mathrm{~s}^{-1}$ during cloudy nights and $1342 \mu \mathrm{mol}$ photons $\mathrm{m}^{-2} \mathrm{~s}^{-1}$ on bright sunny days (zenith at 13:00), and the overall photon flux received throughout the experiment were similar among ponds ( $\pm 6 \%$ of the average total PAR received). Despite the fact that nights are not dark in July at this latitude, the energy at wavelengths relevant for DOM photolysis (UVR) gets very low. Therefore, about $85 \%$ of the daily UV dose of a sunny day is received from 7 to $19 \mathrm{hr}$ (data obtained from Sequoia Scientific Inc. for a sunny day in July; see Laurion and Mladenov 2013). Wind speed varied between 0.3 and $9.7 \mathrm{~m} \mathrm{~s}^{-1}$ (average $3.1 \mathrm{~m} \mathrm{~s}^{-1}$ ) and was $40 \%$ lower at night (average 19:00-7:00 $=2.5 \mathrm{~m} \mathrm{~s}^{-1}$ ) than during the day (average 7:00-19:00 $=3.8 \mathrm{~m} \mathrm{~s}^{-1}$ ). Air temperature varied between $2^{\circ} \mathrm{C}$ and $18^{\circ} \mathrm{C}$ during the incubation period (10-24 July). The water temperature at the incubation depth 94 95 96 97 98 99 100 101 102 103 
1 Table 4. Initial rates of $a_{320}$ changes (over the first $4 \mathrm{~d}$ ) under the four treatments ( $\mathrm{C}=$ filtered water in the dark; $\mathrm{S}=$ filtered water in 55 2 sunlight; $\mathrm{B}=$ unfiltered dark; $\mathrm{BS}=$ unfiltered sunlight), with significant differences relative to control as indicated by a star $(p<0.05)$. 56 Q9 Negative values indicate a loss of CDOM.

Treatment

6

$7 \mathrm{C}$

8 B

$9 \mathrm{~S}$

10 BS

11

(i.e., average temperature between loggers positioned at 0 and $10 \mathrm{~cm}$ used as a proxy for $5 \mathrm{~cm}$ depth) oscillated between $8^{\circ} \mathrm{C}$ $6^{2}$ and $18^{\circ} \mathrm{C}$ along the experiment in the coalescent pond BYL1,

Fig. 1. Thermal profiles of polygonal pond BYL1 (green) and trough 3 pond BYL38 (orange) on a sunny and calm day (18 July) and on a cloudy 54 and windy day (20 July) at 16:00.

Pond

$\rightarrow \operatorname{BYLI}($ polygonal)

$\rightarrow$ BYL38 (trough)

0.8

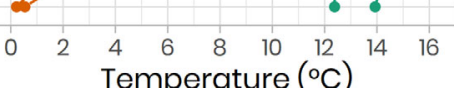

\section{Initial DOM properties of incubated waters}

A gradient in DOM quantity and optical properties can be seen among the selected ponds. While DOC did not vary much (coefficient of variation $\mathrm{CV}, 15 \%$ for an overall average of $\left.9.2 \mathrm{mg} \mathrm{L}^{-1}\right), a_{320}$ (a proxy for CDOM concentration) varied between 13.2 and $67.3 \mathrm{~m}^{-1}$ (CV 70\%), generating wideranging absorptivity values (absorption per unit DOC) as

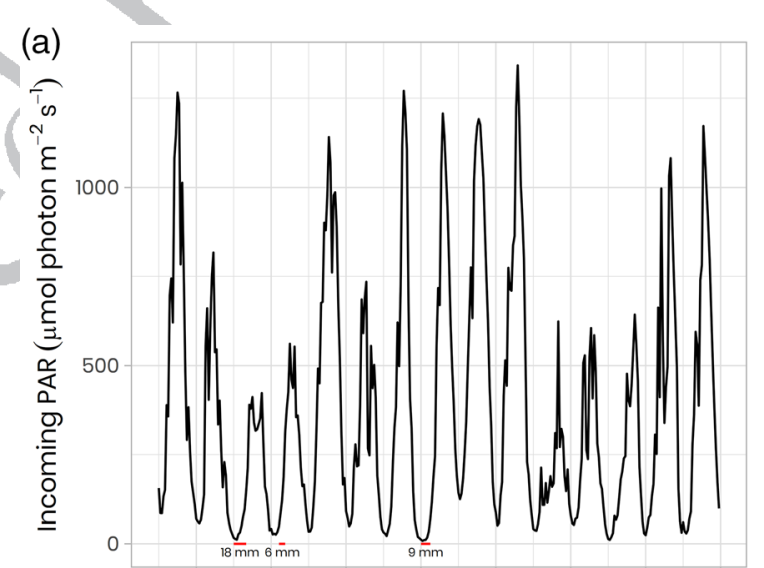

(b)

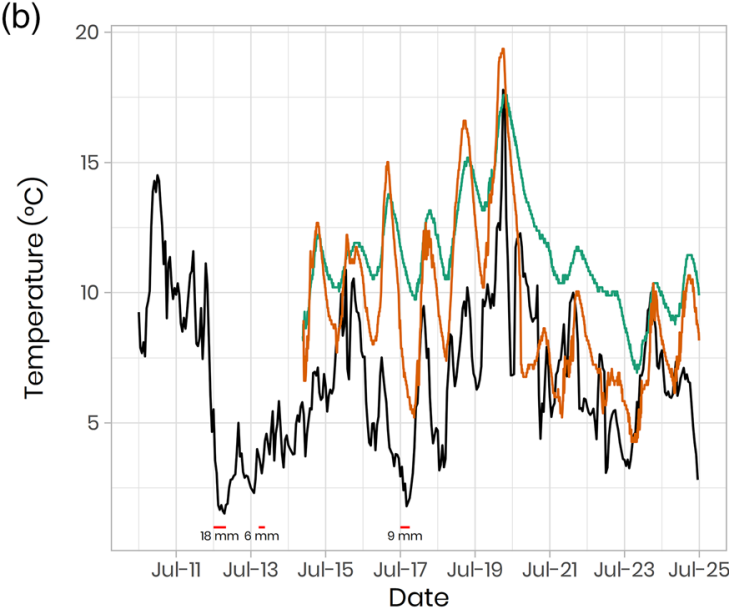

- Air

- BYL38

Fig. 2. (a) Incoming irradiance of the photosynthetically available radiation (PAR) with major rain events indicated by red lines (numbers indicate the amount of received rain), and (b) air temperature (black) and water surface temperature in BYL1 (green) and BYL38 (orange). 
Table 3. Dissolved organic matter fluorescence properties of the four studied ponds at the beginning of the experiments extracted 55 2 with PARAFAC, including the amount of each component $\left(F_{\max }\right.$ of $\left.\mathrm{C} 1-\mathrm{C} 5\right)$ and the total fluorescence $\left(F_{\text {tot }}\right)$ given in Raman units (RU). 3 The percentage of each component to $F_{\text {tot }}$ is given in parentheses. The first two columns indicate the excitation and emission peaks (and secondary peaks in parentheses) of each component.

\begin{tabular}{|c|c|c|c|c|c|c|c|}
\hline $\begin{array}{l}\text { PARAFAC } \\
\text { components } \\
\end{array}$ & $\begin{array}{c}\text { Ex } \\
\text { peaks }(\mathrm{nm})\end{array}$ & $\begin{array}{c}\text { Em } \\
\text { peaks }(\mathrm{nm})\end{array}$ & Description & $\begin{array}{c}\text { BYL1 } \\
\text { coalescent }\end{array}$ & $\begin{array}{c}\text { BYL22 } \\
\text { polygonal }\end{array}$ & $\begin{array}{c}\text { BYL24 } \\
\text { through }\end{array}$ & $\begin{array}{c}\text { BYL38 } \\
\text { through }\end{array}$ \\
\hline & \multicolumn{7}{|c|}{ Fluorescence RU (\%) } \\
\hline $\mathrm{C} 1$ & $<250(320)$ & 440 & Microbial fulvic-like* & $0.37(31)$ & $0.35(36)$ & $0.88(46)$ & $1.27(49)$ \\
\hline $\mathrm{C} 2$ & $<250(300)$ & 390 & HMW humic-like ${ }^{\dagger}$ & $0.24(20)$ & $0.18(19)$ & $0.30(16)$ & $0.44(17)$ \\
\hline $\mathrm{C} 3$ & $<250(360)$ & 422 & Humic-like & $0.21(17)$ & $0.15(16)$ & $0.33(17)$ & $0.33(13)$ \\
\hline $\mathrm{C} 4$ & $270(380)$ & 492 & Terrestrial fulvic-like ${ }^{\S}$ & $0.11(9)$ & $0.10(10)$ & $0.25(13)$ & $0.36(14)$ \\
\hline $\mathrm{C} 5$ & 280 & 334 & $\begin{array}{l}\text { Microbial } \\
\text { tryptophan-like }\end{array}$ & $0.27(23)$ & $0.18(19)$ & $0.13(7)$ & $0.19(7)$ \\
\hline$F_{\text {tot }}$ & - & - & - & 1.20 & 0.97 & 1.89 & 2.58 \\
\hline
\end{tabular}

16 HMW, high molecular weight.

17 *Fulvic-like molecules potentially of a microbial origin as shown in Murphy et al. (2008) for their C2 (EX/EM 315/418), or in Guillemette and del

18 Giorgio (2012) for their C1 (350/450).

19 Timilar to humic-like component U (250(320)/370), found to be widespread but highest in wetlands and forested environments, very labile and associated with freshly produced DOM in Fellman et al. (2010); also similar to microbial humic component C6 (<250(285)/386) in Williams et al. (2013). ${ }^{\ddagger}$ Similar to humic-like peak C (320-360/420-460) in Coble et al. (1990); also similar to humic-like C1 (240-320/428) in Stedmon et al. (2003).

${ }^{\S}$ Fulvic-like molecules of a terrestrial origin and widespread, similar to C3 (260(370)/490) in Murphy et al. (2008).

22 "Similar to tryptophan-like component (270-280/330-368) in Fellman et al. (2010). 23

24 illustrated by the SUVA index (Table 1). Trough ponds are 25 characterized by higher CDOM $\left(a_{320}\right)$ and more colored DOM 26 (SUVA) as compared to polygonal ponds. Dissolved iron 27 (Fe) also varied widely among ponds, the highest value 28 observed in the eroding trough pond BYL38 $\left(3.05 \mathrm{mg} \mathrm{L}^{-1}\right)$, 29 which is known to affect DOM optical properties (Poulin 30 et al. 2014). Even if part of DOM color comes from its interac31 tion with $\mathrm{Fe}$, the corrected SUVA values remain higher in 32 trough ponds than in polygonal ponds (values in parenthe33 ses). The lower absorption slopes $\left(S_{285}\right)$ and higher SUVA

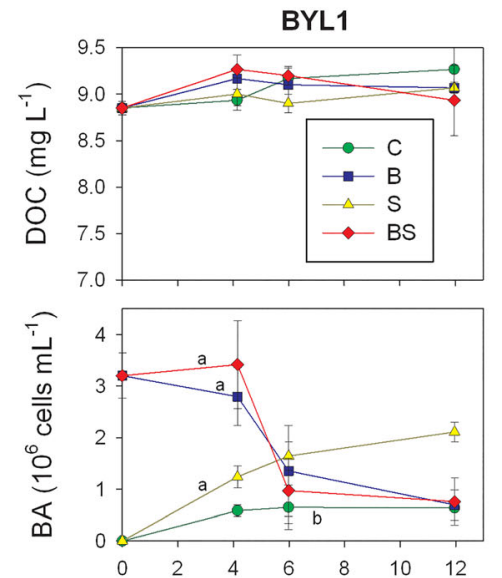

values together indicate the presence of larger, more aromatic molecules in the DOM pool of trough ponds affected by soil erosion, although the proportion of DOM leached from recently eroded permafrost soils was not determined in the present study.

The EEMs also reveal higher FDOM in trough ponds, with components corresponding to previously identified fluorophore groups (Table 3). Trough ponds had a larger fraction of fulvic-like $\mathrm{C} 1 \quad\left(>46 \%\right.$ of $\left.F_{\mathrm{tot}}\right)$ and a smaller fraction of tryptophan-like C5 (7\%) as compared to the polygonal ponds
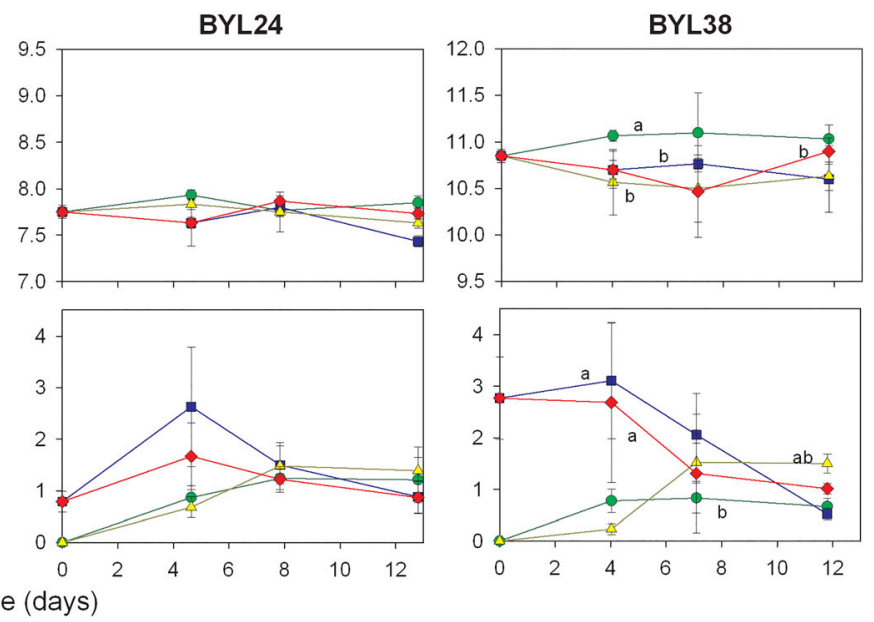

Fig. 3. Experimental changes in average $( \pm S D)$ dissolved organic carbon (DOC; first row of panels) and bacterial abundance (BA; second row) over $12 \mathrm{~d}$ of incubation under four treatments ( $\mathrm{C}=$ filtered water in the dark; $\mathrm{S}=$ filtered water in sunlight; $\mathrm{B}=$ unfiltered dark; $\mathrm{BS}=$ unfiltered sunlight), for the coalescent polygonal pond BYL1, polygonal pond BYL22, stabilized trough pond BYL24 and erosive trough pond BYL38. Although the scale range may vary among ponds, the $y$-axis increments are consistent for each parameter shown. The different letters indicate the significant differences between treatments according to a Tukey HSD or Tukey-Kramer multiple comparison. 
41 ( $<36 \%$ of $\mathrm{C} 1$ and $>19 \%$ of $\mathrm{C} 5$ ). The coalescent polygonal 42 pond BYL1 presented the highest quantity of Component C5 43 (0.27 RU, or 23\%); this pond also showed the highest BIX 44 value (attributed to a larger fraction of autochthonous DOM; 45 Huguet et al. 2009). While varying amounts of C2, C3, and $46 \mathrm{C} 4$ were found within the four ponds, their proportions were 47 relatively similar among ponds, with differences always 48 remaining below 5\%. It is only Components C1 and C5 that 49 varied substantially among ponds initially.

50

\section{Treatment effects on microbial abundance and DOC}

52 The filtered (S and $\mathrm{C}$ ) water treatments showed increases in * b bacterial counts after a few days (Fig. 3). This bacterial 54 regrowth was higher under sunlight than in the dark (control)
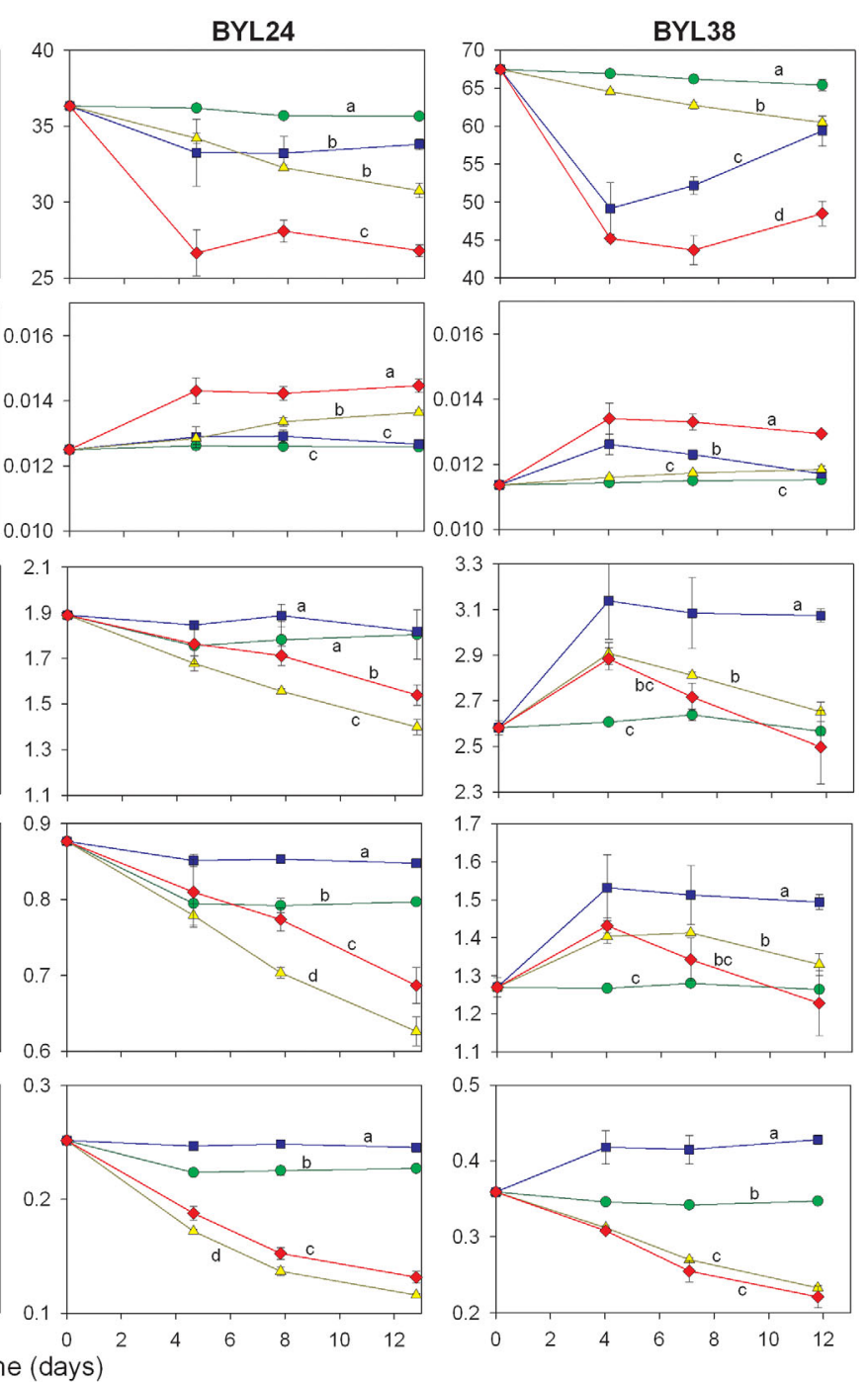

for BYL1, BYL22, and BYL38 (planned contrast on S and C 95 treatments only; $p<0.018$ ). In unfiltered treatments (B and 96 BS), a decrease in bacterial abundance over $12 \mathrm{~d}$ was rather 97 observed, potentially caused by microzooplankton grazing or 98 competitive interactions under the experimental conditions. There was no significant difference in bacterial abundance patterns between B and BS treatments (planned contrast on B and BS treatments only; $p>0.166$ ), and the final bacterial abundance seems to converge among treatments.

Overall, the DOC did not change significantly over the $12 \mathrm{~d}$ of incubation in any of the treatments (Fig. 3; $p>0.152$ on time effect; Table S1), with a CV of less than 5\% among all treatments and replicates of any specific pond (less than $3 \%$ when excluding the time zero of BYL22 for which the
99

100 101 102 103 105 108 


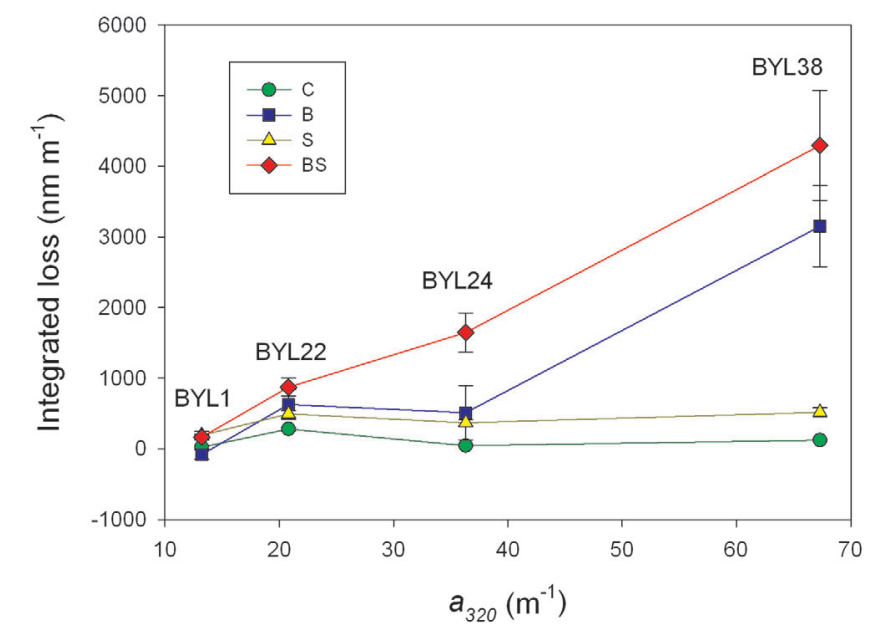

Fig. 5. Integrated CDOM absorption losses (average $\pm S D$ ) after $4 \mathrm{~d}$ of incubation under four treatments $(C=$ filtered water in the dark; $S=$ filtered water in sunlight; $B=$ unfiltered dark; $B S=$ unfiltered sunlight) as a function of initial CDOM ( $a_{320}$ used as a proxy on the $X$-axis) in the four studied ponds. The integrated loss was calculated as the area under the curve of a $(\lambda)$ at time zero minus a $(\lambda)$ after $4 \mathrm{~d}$.

22 incubation water was collected after heavy rainfall on 12 July; 23 see discussion for this case). Only was there a treatment effect 24 detected for BYL38 $(p=0.011)$ and BYL22 $(p=0.0004)$, but 25 with differences among treatments of less than $0.4 \mathrm{mg} \mathrm{L}^{-1}$. 26 The precision of the TOC analyzer (quantification limit of about $0.5 \mathrm{mg} \mathrm{L}^{-1}$ ) was not high enough to resolve the subtle 28 changes that occurred at this site over the experimental time 29 frame. Therefore, despite CDOM becoming less colored over 30 time (see below), neither the microbial (Treatment B) nor the 31 photochemical (Treatment S) transformation of DOM, and 32 not even the microbial consumption of the photoproducts 33 (included in treatment BS), generated significant mineraliza34 tion of DOM into $\mathrm{CO}_{2}$.

36

\section{Treatment effects on CDOM}

38 Sunlight (Treatment S) generated a loss of color over time, B. 9 as expressed by the decrease of $a_{320}$ (top panels in Fig. 4), with 40 higher (in BYL1), comparable (in BYL22 and BYL24) or lower 41 loss rates (in BYL38) than those caused by microbial degrada42 tion (Treatment B). In treatments containing the original bio-

43 mass of bacteria at time zero (B and BS), complex dynamics

44 were observed in trough ponds BYL24 (CDOM loss slowing

45 down) and BYL38 (CDOM increasing after an initial loss). The

46 absorption slope $S_{285}$ increased over time with a plateauing

47 (BYL24) or reversing trend (BYL38). The two-way ANOVA per-

48 formed on $a_{320}$ and $S_{285}$ indicate significant treatment effects

$49(p<0.0002$; details provided in Supporting Information 50 Table S1).

51 A comparison of the initial change rates over $4 \mathrm{~d}$ of incuba52 tion (at the first subsampling date; Table 4) minimizes the 53 confounding effect caused by this bacterial regrowth in the $\mathrm{S}$ 54 treatments (Fig. 3) and avoids the complex DOM production dynamics sometimes occurring thereafter (e.g., the decrease in 55 $a_{320}$ of BYL38 reversing after $4 \mathrm{~d}$; Fig. 4 ). These results indicate 56 that microbial degradation caused a decrease of $a_{320}$ at a rate 57 varying from $0.5 \% \mathrm{~d}^{-1}$ (BYL1) to $6.7 \% \mathrm{~d}^{-1}$ (BYL38), which 58 was always higher than in the control treatment (significant 59 at $p<0.05$ for BYL22 and BYL38). On the other hand, photo- 60 bleaching rates varied from $1.1 \% \mathrm{~d}^{-1}$ (BYL38) to $3.4 \% \mathrm{~d}^{-1}$ (BYL22), or from $0.33 \mathrm{~m}^{-1} \mathrm{~d}^{-1}$ (BYL1) to $0.72 \mathrm{~m}^{-1} \mathrm{~d}^{-1}$ (BYL38) for the amount of color lost per day (at $320 \mathrm{~nm}$ ). The concomitant effect of sunlight and microbes (BS) presented the highest rates reaching $8.2 \% \mathrm{~d}^{-1}$ in through pond BYL38 (absolute loss rate also highest in this pond). The concomitant loss was larger than the sum of B and S losses only in trough pond BYL24.

To assess the spectral loss of DOM color, we integrated from 250 to $700 \mathrm{~nm}$ the loss of absorption after $4 \mathrm{~d}$ of incubation (Fig. S1). There was a significant treatment effect on this integrated short-term loss for all four ponds $(p<0.0005)$, with treatment BS generally showing the highest losses. When normalized to the area below the initial absorption curves, this integrated loss over $4 \mathrm{~d}$ for treatment BS varied from $6 \%$ (in coalescent pond BYL1) to 36\% (in trough pond BYL38). Interestingly, the integrated loss increased as a function of initial CDOM ( $a_{320}$ used as a proxy for the quantity of CDOM) for B and BS treatments but did not change with CDOM for the S treatment (and C; Fig. 5).

\section{Treatment effects on FDOM and overall DOM trends}

By contrast, the metrics for FDOM $\left(\mathrm{F}_{\text {tot }}, \mathrm{C} 1\right.$ and $\mathrm{C} 4$ shown in Fig. 4, other PARAFAC components can be found in Supporting Information Fig. S2, and all data are available in repository Laurion et al. 2020) did not follow the same patterns as absorption, especially in the presence of microbes where $F_{\text {tot }}$ generally increased (BYL22, BYL38) or remained constant (BYL1, BYL24). $F_{\text {tot }}$ decreased under sunlight (S and BS) in most ponds, as did the $a_{320}$ values, but this was not seen in trough pond BYL38 where only C4 decreased with sunlight, while $\mathrm{C} 2$ and $\mathrm{C} 3$ presented an increasing trend. Overall, Component C5 did not show any clear patterns, except in coalescent pond BYL1 where it slightly decreased under sunlight, similar to the other four components. The highest loss rate in FDOM was observed for $\mathrm{C} 1$ in trough pond BYL24 (0.25 RU lost over $12 \mathrm{~d}$ under $\mathrm{S}$ treatment, or $29 \%$ loss).

Principal component analyses (PCA) were applied on all DOM properties measured along the experiments (excluding measurements at time zero; Fig. 6). From $68 \%$ to $81 \%$ of the variance was explained by the first two components, depending on the ponds. The PCA shows a unique DOM signature among treatments for all four ponds, with little overlapping of the polygons defined by time subsamples, suggesting that the four treatments produced DOM pools with distinctive characteristics. Subsamples of treatment BS (red) show the largest dispersal in DOM properties, while control 6 7 9 61 62 63 64 65 66 67 68 69 70 71 72 73 74 75 76 77 78 79 81 


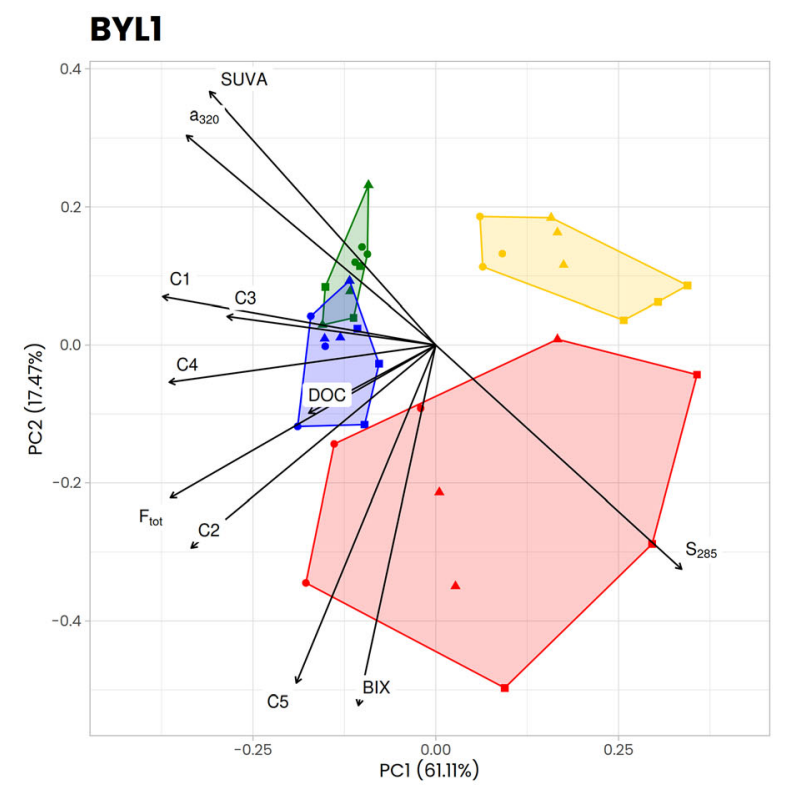

BYL24

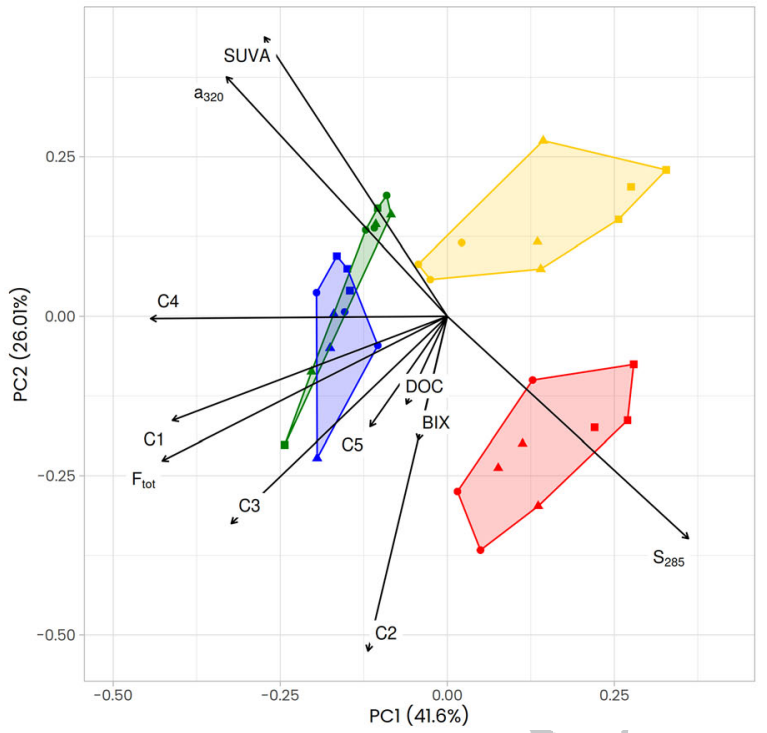

\section{BYL22}
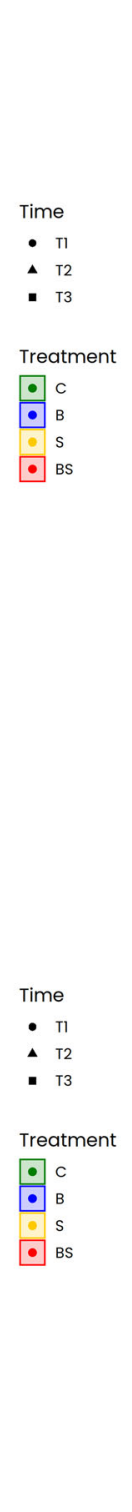

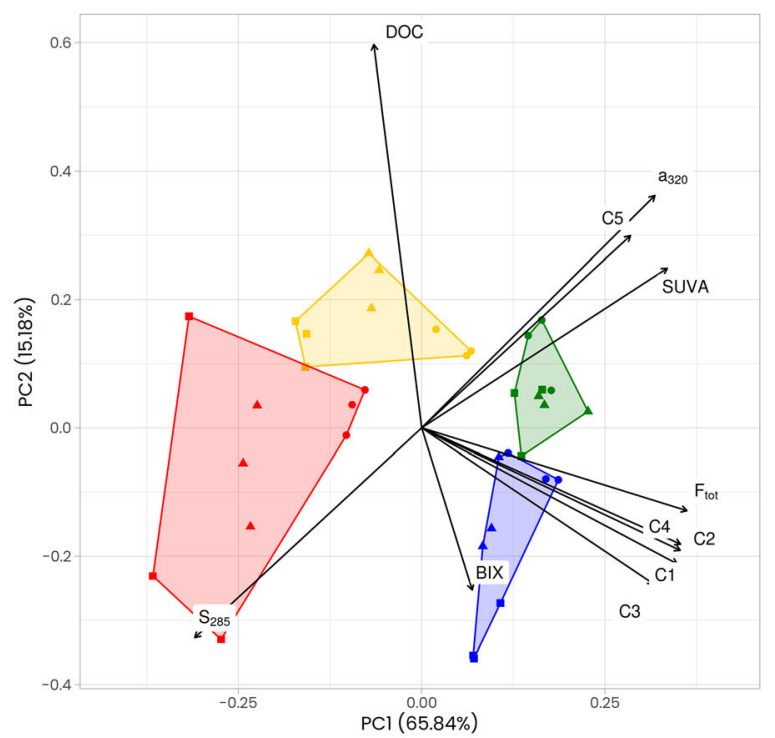

BYL38

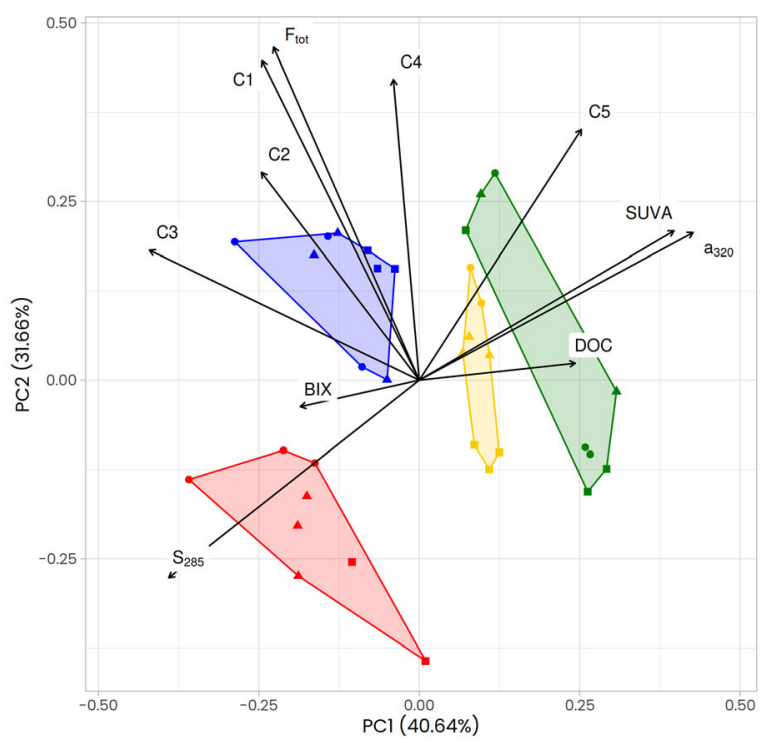

Fig. 6. Principal component analyses for the four ponds including all DOM variables and using the same color code as in Figs. 3-5. Each data point rep- 93 resents the DOM signature of a bottle replicate at a subsampling time (excluding time zero). Replicates are distinct and different symbols are used for subsampling done after about $4 \mathrm{~d}$ (circles), $8 \mathrm{~d}$ (triangles), and $12 \mathrm{~d}$ (squares).

subsamples (green) were closest to each other. Trough pond BYL38 was an exception again, with the sunlight treatment showing the narrowest change over time (yellow).

\section{Discussion}

\section{Limited pelagic mineralization of DOM in small tundra} ponds

Some studies have explored the microbial mineralization of permafrost organic matter using dark incubations (reviewed by Vonk et al. 2015), while others focused on its photochemical decay using natural or artificial radiation 98 (e.g., Cory et al. 2013; Laurion and Mladenov 2013; Stubbins 99 et al. 2017). Studying the combined effects of microbial and 100 light degradation processes is important because they are 101 occurring concurrently in aquatic ecosystems, but such studies 102 are scarce for Arctic regions (Ward et al. 2017; Shirokova 103 et al. 2019). This simultaneous interaction influences the fate 104 of DOM along the aquatic continuum and may affect the 105 transfer of ancient C stocks to the atmosphere (Cory and 106 Kling 2018) or to coastal waters. However, the tundra ponds 107 considered in this study presented undetectable DOC losses 108 
1 and therefore low mineralization of DOM into $\mathrm{CO}_{2}$ under nat2 ural conditions. This was the case when both microbes and 3 sunlight were acting independently (treatments B or S) and 4 concurrently (BS). It means that neither direct photo5 mineralization of DOC nor the microbial mineralization of 6 DOM photoproducts were high enough to be statistically significant over $12 \mathrm{~d}$. These observations also apply to a pond 8 deeply affected by permafrost thermoerosional processes (trough pond BYL38) and receiving aromatic C (higher CDOM 10 and SUVA) from the surrounding peaty soils during the 11 thawing season. On the other hand, transformation of the 12 DOM pools clearly occurred (see the section below on "Trans13 formation of DOM related to mixing regime and historical 14 decay").

15 The limited DOM mineralization obtained in the present 16 study applies to water that was sampled on 10-12 July from 17 the pelagic zone of the ponds, not long after ponds have fin18 ished melting (extending from 15 to 30 June), and at the 19 beginning of the warming period extending over July at this 20 site (based on water thermal profiles; unpublished results).

21 The period before 10 July was very dry ( $2 \mathrm{~mm}$ of rain recorded 22 locally since 19 May), and thus DOM inputs to ponds were 23 limited in previous weeks. It is possible that the OC leaching 24 earlier during the snowmelt period, or after large rain events 25 and as the active layer deepens later in the season, would pre26 sent higher mineralization rates. Studies acknowledge the 27 importance of considering seasonality when studying DOM 28 bacterial and photochemical mineralization in rivers (Mann 29 et al. 2012) or in lakes (Vachon et al. 2016). Because small tun30 dra ponds have stagnant waters, small volume and dominant 31 littoral zones, the DOM pool of these water bodies is likely 32 very responsive to rain events and previous light exposure. 33 Such responses have been shown for a subarctic polymictic 34 lake (Gibson et al. 2001) and other larger lakes (Catalán 35 et al. 2016).

36 Other studies have presented reduced or nondetectable 37 DOM mineralization (i.e., DOC loss) in frozen peat bogs 38 (showing low photolability and biolability; Shirokova 39 et al. 2019) or Yedoma permafrost leachates (showing low 40 photolability; Stubbins et al. 2017). The biolability of soil 41 organic matter from northern Eurasia (including yedoma, 42 cryoturbated soils and peatlands; Kuhry et al. 2020) and inte43 rior Alaska (Wickland et al. 2018) was also considered rela44 tively low. This is quite different from what was observed in 45 other studies, where sometimes high mineralization rates were 46 reported along the aquatic continuum or from permafrost 47 leachates (Cory et al. 2013; Vonk et al. 2013; Drake et al. 2015; 48 Mann et al. 2015). These discrepancies in DOM mineralization 49 rates across the Arctic need to be better understood before up50 scaling exercises provide meaningful estimates (Koehler 51 et al. 2014). Discrepancies are likely driven by differences in 52 the parent material leaching into aquatic systems (e.g., its 53 organic content, the transformation of organic matter before 54 and during its incorporation into permafrost), the historical exposure to microbial and photochemical degradation (time 55 since thaw, water residence time) and the physicochemical 56 conditions of receiving water bodies (e.g., morphology, 57 mixing and light regimes, $\mathrm{pH}$ ), all affecting the molecular 58 composition of the DOM pool examined at a specific time, 59 and thus its reactivity (Abbott et al. 2014). For example, the 60 rapid biomineralization of Pleistocene-age permafrost C 61 leached from Yedoma soils was highly linked to the presence 62 of low-molecular-weight, hydrogen-rich aliphatic compounds, 63 quickly disappearing after entering the hydrologic network 64 (Drake et al. 2015), and underlining the importance of consid- 65 ering $\mathrm{C}$ cycling at the landscape scale. It is worth mentioning 66 that some of the divergence among studies could also be 67 linked to variations in the definition of lability and in the cho- 68 sen experimental setup. For example, variable filtration effi- 69 ciencies in removing microbes or variable incubation lengths can lead to differing microbial regrowth or taxonomic composition that can affect the outcome of lability assays (Dean et al. 2018).

What is important to underline is that the low pelagic DOM mineralization observed here corresponds to a relatively cold moment on the tundra (i.e., a moment of reduced Arganic matter movement and processing). Such cold moments can potentially be under-represented in the literature and highly dependent on precipitation regimes. As pointed out by Wen et al. (2020), catchments serve as producers and storage reservoirs for DOM under hot and dry conditions, and transition into DOM exporters under wet and cold conditions. The predicted increase in annual precipitation for Arctic tundra regions, particularly in winter and fall (Bring et al. 2016), will control DOM export to aquatic ecosystems and the balance between autochthonous/allochthonous sources (Osburn et al. 2019), which will certainly affect seasonal patterns in DOM mineralization.

\section{The photostimulation of bacterial growth}

The absence of significant DOM mineralization does not mean sunlight was not affecting DOM and microbes. One noteworthy aspect of our results is the observed stimulation of bacterial growth after the water has been filtered and exposed to sunlight (treatment S vs. C in Fig. 3 last row). Even though $0.2-\mu \mathrm{m}$ filtration has been extensively used to sterilize water, this step can leave cells behind, generating a bias when the goal is to isolate photochemical from biological effects. Therefore, special care should be taken when filtering water, and cell abundance always controlled. Beyond this problem, the stimulated growth of bacteria left behind observed here suggests that cells were benefiting from the exposure to sunlight. Such stimulation has been reported in various aquatic systems (e.g., Lindell et al. 1995; Wetzel et al. 1995; Miller and Moran 1997).

In general, bacterial growth stimulation by sunlight is attributed to the production of smaller, more aliphatic and oxidized molecules by hydroxyl radical reactions or other 6
8
9
7
4
6
6
6
6
6 71 72 
1 photoreactions (Ward et al. 2017). The photochemical release 2 of nutrients from DOM could also be involved (Vähätalo 3 et al. 2003). Interestingly, Ward et al. (2017) have shown that 4 sunlight significantly increased microbial respiration when 5 photo-alteration produced molecules that native microbial 6 communities used prior to light exposure, but the contrary also occurred (decreased respiration when photo-altered prod8 ucts were not familiar to native communities). On the other

9 hand, we cannot exclude that part of the growth stimulation

10 observed in the present study under sunlight was linked to

11 the slightly higher temperature caused by the absorption of

12 heat by water (on average $0.7^{\circ} \mathrm{C}$ higher for coalescent pond

13 BYL1, and $1.1^{\circ} \mathrm{C}$ higher for trough pond BYL38), a potential 14 indirect effect that also deserves attention.

15 The bacterial growth in filtered treatments could only be 16 detected in the absence of protozoan predation and under the

17 reduced competition that occurred after the microbial popula-

18 tion was significantly removed by filtration. Considering the

19 small $\mathrm{C}$ content of a few millions of bacterial cells (totaling

$20<1 \mathrm{mg} \mathrm{C} \mathrm{L}^{-1}$ even considering large bacteria, conversion fac-

21 tors available in the literature, and a fraction lost through res-

22 piration), the absence of any significant decrease in DOC

23 despite the bacterial stimulation observed here is plausible

24 over the time frame of the experiment. For example, recent

25 studies revealed the widespread occurrence of candidate phyla

26 radiation bacteria that are very small cells $(<0.2 \mu \mathrm{m}$; Castelle

27 et al. 2018), not removed by conventional filtration, and with

28 a role yet to be defined. Further research involving molecular

29 tools and bacterial production are needed to more directly

30 evaluate the biolability of differing DOM pools and better

31 inform future experimental design.

32

33 Transformation of DOM related to mixing regime and 34 historical decay

35 This study shows that four nearby tundra ponds can have 36 different patterns in DOM photochemical and microbial trans-

37 formation, which are likely driven by the quality of the DOM

38 pool at the start of the experiment. This is in agreement with

39 results from studies in subarctic lakes showing changes in

40 composition and biological reactivity along DOM gradients

41 (e.g., Berggren et al. 2019). Notably, the photodegradability of

42 DOM has proven to be related to its color (Lapierre and del

43 Giorgio 2014). In the present study, the fastest losses in color

44 were indeed observed in the most colored pond (erosive

45 trough BYL38; Tables 1 and 4).

46 Around $10 \%$ to $27 \%$ of CDOM $\left(a_{320}\right)$ was lost after $12 \mathrm{~d}$ of 47 incubation under sunlight, with slower, similar, or faster pho-

48 tochemical decay than the microbial decay (7\%-31\% loss;

49 Fig. 4). This was accompanied by an inverse rising trend in

50 absorption slopes at short wavelengths (illustrated by $S_{285}$ ).

51 Photochemical alteration was shown to produce less colored

52 DOM in Arctic lakes and rivers (e.g., Mann et al. 2012; Cory

53 et al. 2014). CDOM losses accompanied by rising absorption

54 slopes and little or no production of $\mathrm{CO}_{2}$ (or limited DOC losses) is called partial photooxidation, and is usually 55 attributed to the transformation of aromatic or high-molecu- 56 lar-weight DOM into aliphatic or lower-molecular-weight 57 compounds (Cory and Kling 2018). Although photo-altered DOM molecules through partial photooxidation were previously shown to accelerate the microbial processing of permafrost DOM (e.g., Cory et al. 2013; Ward et al. 2017), this was not significant in the studied ponds since BS treatments were not showing significant DOC losses despite marked changes in CDOM and FDOM. Nonetheless, the bacterial regrowth observed under sunlight suggests that partial photooxidation may have occurred and may stimulate DOM mineralization to a varying extent, depending on the mixing regime that controls sunlight exposure and water temperature.

The studied water bodies present different mixing regimes. Coalescent pond BYL1 is a well-mixed system of less than a meter deep, efficiently exposing its DOM to elevated irradiance. Therefore, when this pond was sampled after a long period of dry conditions, it presented the lowest SUVA index among the four ponds (Table 1) and a particularly slow photodecay rate (see the CDOM loss rates for $S$ treatment in Table 4). The measured rate might even be overestimated since maintaining bottles at the surface was artificially increasing the irradiance dose for this well-mixed pond. The same pond was studied during the previous summer under similar incubation conditions but 1 week later (18-31 July 2009; Laurion and Mladenov 2013), and results indicate that CDOM photodecay was slightly faster $\left(0.46 \mathrm{~m}^{-1} \mathrm{~d}^{-1}\right.$ in 2009 as compared to $0.33 \mathrm{~m}^{-1} \mathrm{~d}^{-1}$ in the present study). In this specific example, $16.5 \mathrm{~mm}$ of rain had fallen over the 2 weeks preceding the experiment in 2009, as compared to $2.0 \mathrm{~mm}$ in 2010, putatively transporting more DOM freshly leached into the pond, which may explain the faster photodecay. Moreover, incident radiation was $64 \%$ lower in 2009 as compared to 2010 over the 2 weeks preceding the experiment (but with similar radiation during the experimental days; CEN 2018), lowering the historical photodegradation of the DOM pool (i.e., before it was sampled). Therefore, the weather condition previous to water sampling is a critical aspect of any experimental assessment that needs to be taken into account.

In the other three cases, maintaining bottles at the surface may well reflect the in situ conditions (at the surface) as the ponds are either very shallow (polygonal pond BYL22) or stably stratified in July (trough ponds BYL24 and BYL38). Partial mixing of the water column (mainly observed at night; unpublished data), however, renews water masses at the surface to a certain extent. Because exposure to sunlight at depth is limited in colored waters, longer residence time combined with periodic mixing should favor DOM removal at the scale of a lake or along the river continuum (Cory et al. 2014; Groeneveld et al. 2016). In this context, we expected that pond BYL22 would have presented a similarly low decay rate as BYL1 considering its shallowness $(\sim 0.2 \mathrm{~m})$ and the previous exposure of its DOM pool to an overall high irradiance, but

$$
6
$$$$
57
$$$$
58
$$$$
59
$$$$
60
$$$$
61
$$$$
62
$$$$
63
$$$$
64
$$$$
65
$$ 
1 instead high CDOM loss under sunlight was observed (similar 2 to BYL38; Fig. 4; Table 4). Pond BYL22 was however sampled $31 \mathrm{~d}$ later than the other three, right after a heavy rainfall event (18 mm). This likely brought in fresh leachates of DOM. Many 5 studies have shown a positive correlation between precipita6 tion and $\mathrm{CO}_{2}$ emissions or photochemical mineralization of DOM (e.g., Rantakari and Kortelainen 2005; Suhett et al. 2007; 8 Groeneveld et al. 2016). In the case of BYL22, the starting 9 DOM properties (not particularly chromophoric or fluores10 cent, see SUVA and $F_{\text {tot }}$ in Tables 1 and 3) and the sharp 11 decrease in DOC observed at the start of the experiment for all 12 treatments (Fig. 3) suggests that the rain event leached 13 uncolored DOM that may be prone to flocculation under the 14 pelagic conditions of this pond, although it is colored DOM 15 flocculation that was previously observed (e.g., von 16 Wachenfeldt and Tranvik 2008). Alternatively, we cannot 17 exclude the possibility that the DOC quantification at time 18 zero was biased (no replicate). This pattern needs to be con19 firmed by paying more attention to DOM properties before 20 and after rain events, controlling with direct measurements of $21 \mathrm{CO}_{2}$ and flocculates, and using methods that also characterize 22 the nonchromophoric fraction of DOM. The DOM composi23 tion in such small water body (volume $<15 \mathrm{~m}^{3}$ for BYL22, 24 while BYL1 was $>150 \mathrm{~m}^{3}$ ) is likely very dynamic, but this is 25 rarely assessed as we generally tend to aim for larger, less 26 ephemeral water bodies. Yet, large quantities of DOM may still 27 be mineralized in these water bodies at the landscape scale, 28 and to account for this, better spatiotemporal coverage is 29 needed.

30

\section{DOM recycling in small tundra ponds}

Significant CDOM losses were also observed in dark incuba33 tions (B treatments), but these losses cannot be clearly associ34 ated with microbial mineralization since they were not 35 accompanied by substantial DOC losses, unless recycling was 36 very efficient. It was rather linked to a microbial conversion of 37 molecules, and these were apparently fluorescent compounds 38 in ponds BYL22 and BYL38 (B treatment in Fig. 4). Substantial 39 production of $\mathrm{C} 1$ compounds, a group of humic-like mole40 cules previously associated with DOM of a microbial origin 41 (Murphy et al. 2008), was observed in these two ponds. The 42 consumption of chromophoric/aromatic molecules concur43 rent with a production of fluorescing molecules was also 44 found in lacustrine systems of the temperate zone, and largely 45 depended on DOM source (Guillemette and del Giorgio 2012).

46 The production of CDOM and FDOM has also been observed 47 in laboratory incubations of subarctic lake DOM (Berggren 48 et al. 2019). Bacteria tend to be presented in the literature as 49 low-molecular-weight nonaromatic DOM consumers, with 50 photodegradation often causing DOM properties to shift in an 51 opposite direction than biodegradation (Hansen et al. 2016).

52 These general trends may be inadequate for thermokarst lakes

53 deeply affected by permafrost soil erosion, receiving organic 54 matter with different reactivities to microbial and photochemical degradation than allochthonous matter from 55 nonpermafrost regions or from regions not affected by ther- 56 mokarstic erosion. Moreover, as pointed out by Berggren et al. (2019), the common assumption that CDOM has a terrestrial origin may need to be revised.

Overall, the PCA analysis indicates that presence of the complete microbial community (unfiltered) clearly generated changes in the composition of fluorophores, while sunlight was particularly driving changes in DOM molecular size (absorption slope). In particular, eroding trough ponds such as BYL38 may be deeply influenced by soil microbial assemblages specialized in processing large aromatic molecules (see details on bacterial assemblages in Negandhi et al. 2014, where the term runnel pond was used instead of trough ponds). Roth et al. (2019) concluded that plant material is extracellularly decomposed to smaller molecules, which are then consumed and, in part, mineralized or transformed to larger microbialderived molecules forming a secondary pool of organic matter (potentially more fluorescent). The reverse trend in CDOM observed along the 12-day incubation in BYL38 (i.e., a decrease in CDOM followed by an increase) might have resulted from such a turnover dynamic. Extracellular decomposition in ponds from enzymes produced in nearby soils could also help explain the absence of significant DOC mineralization despite clear CDOM changes. Moreover, microbial degradation was more effective than photodegradation in BYL38, suggesting a higher proportion of bioreactive molecules or a more efficient microbial community eroded from soils (Ward et al. 2017). In the PCA, BYL38 (lowest transparency) showed the narrowest changes in DOM properties for $\mathrm{S}$ treatment (Table 1, Fig. 6). The CDOM losses integrated over the first $4 \mathrm{~d}$ of incubation and plotted as a function of initial CDOM (Fig. 5) increased for treatments with bacteria (B and BS) but not under filtered sunlight or control treatments (S and $\mathrm{C}$ ). This suggests that conditions in colored trough ponds are leading to a particularly dynamic transformation of the DOM pool, potentially linked to the import of native soil microbes. Molecular-level characterization of DOM (e.g., with ultrahigh-resolution mass spectrometry, nuclear magnetic resonance spectroscopy or pyrolysis-gas chromatography-mass spectrometry; Lennon et al. 2013; Roth et al. 2019) is needed to further explain differences among ponds, but they are likely linked to the relative inputs by benthic primary producers and eroding peaty soils. Since both of these DOM sources will respond to climate change through different mechanisms (Osburn et al. 2019), their transformation and fate need to be explored in more detail and with consideration of microbial food web interactions.

\section{The dominance of benthic $\mathrm{CO}_{2}$ production}

Previous studies on trough ponds at this site (including BYL24 and BYL38) showed that these water bodies are most often largely supersaturated in $\mathrm{CO}_{2}$ in July (Laurion et al. 2010; Bouchard et al. 2015), with surface concentrations reaching$$
56
$$$$
57
$$$$
58
$$ 
1 up to $619 \mu \mathrm{M}$ (median $=50 \mu \mathrm{M}, n=225$ for 31 ponds; 2 unpublished results). Therefore, the slow DOM mineralization 3 rates observed in the present study suggest that most of the $4 \mathrm{CO}_{2}$ produced during the peak summer season is rather associ5 ated to benthic OM processing such as shown in small boreal 6 lakes (Kortelainen et al. 2006), and/or to lateral transport of 7 adjacent soil pore water (Campeau et al. 2018). There was a 8 net production of $\mathrm{CO}_{2}$ when surface sediments of the same 9 four ponds were incubated over a few days in the dark, and 10 faster production in trough ponds compared to polygonal 11 ponds (particularly for BYL38; see Table 2 in Negandhi 12 et al. 2016). This result indicates that particulate OM depos13 ited at the bottom of these water bodies, either through per14 mafrost erosion, DOM flocculation or primary production, is 15 biolabile. Determining the fate of these different sources of $16 \mathrm{OM}$ under the projected summer lengthening, stratification 17 strengthening and altered precipitation regime will be particu18 larly relevant to climate modelers as they would not generate 19 the same feedback onto climate.

20

21

\section{Conclusions}

23 DOM mineralization in the pelagic zone of isolated tundra 24 ponds was not significant at the present study site, contrary to 25 what was found in permafrost leachates, headwater creeks or 26 rivers of other Arctic regions. Differing parent material among 27 sites (permafrost extent, ice content, historical deposition, dia28 genesis, relief; Tank et al. 2020) potentially generates diverse 29 assemblages of molecules with a wide range of bio- and photo30 reactivity, but the difference is also likely linked to the 31 moment when water was sampled. In the present study, it 32 happened to follow a dry period of many weeks. Although the 33 DOM pool in these light-exposed water bodies appeared very 34 reactive, the quantum yield for photochemical mineralization 35 of DOC was apparently not high. There are potentially other 36 moments during the short Arctic summer, including early 37 spring and after rainfall events, when ponds receive pulses of 38 DOM leaching from surrounding soils with a higher minerali39 zation potential. The static nature of tundra ponds during 40 summer, with their long water retention time, may thus con41 strain hot moments (i.e., periods of intense mineralization) 42 when water moves and transports C on the landscape, other43 wise pelagic DOM mineralization rapidly reaches stable state.

44 Tundra ponds can dominate the landscape in certain 45 regions and are exposed to increasing radiation as summers 46 lengthen. They are also facing dynamic changes in the 47 amount of ancient and modern $\mathrm{C}$ they receive as permafrost 48 thaws and plants grow. The contrasting results on the effects 49 of sunlight on DOM mineralization seen in the literature 50 merit further assessments over a wider range of water body 51 types and landscapes, while accounting for the age of mineral52 ized C pools. These assessments will need to exploit recent 53 methodological approaches to characterize DOM and 54 microbes in a more holistic approach and exploit isotopic tracers to decipher current $\mathrm{C}$ pathways and make reliable projections as the climate changes.

To account for the effect of sunlight on permafrost $\mathrm{C}$ mineralization in freshwaters and scale this up, assessments need to be done (1) under natural sunlight exposure considering the mixing regime that can be quite different among tundra ponds and compared to larger lakes and rivers, (2) along the open-water season accounting for rain events and active layer deepening, and (3) controlling for bacterial abundance and DOM flocculation. Working in situ with an experimental approach has many advantages: it allows for the use of natural sunlight that is complex to mimic, and it minimizes changes in microbial assemblages and DOM prior to starting the experiments. Lab conditions are well suited to working on leachates from peat cores or vegetation materials that can be kept frozen for later experiments. Efforts should be given to applying standardized protocols (e.g., Vonk et al. 2015) but considering the logistical constraints associated with sampling in the Arctic. Although there are challenges associated with studying $\mathrm{C}$ mineralization in remote Arctic regions, the strong rates and contrasting trends observed among the few regions studied and the huge $\mathrm{C}$ stock involved call for urgency to improve future projections.

\section{References}

Abbott, B. W., J. R. Larouche, J. B. Jones, W. B. Bowden, and A. W. Balser. 2014. Elevated dissolved organic carbon biodegradability from thawing and collapsing permafrost. J. Geophys. Res. Biogeosci 119: 2049-2063.

Abnizova, A., J. Siemens, M. Langer, and J. Boike. 2012. Small ponds with major impact: The relevance of ponds and lakes in permafrost landscapes to carbon dioxide emissions. Global Biogeochem. Cycles 26: GB2041.

Berggren, M., C. Gudasz, F. Guillemette, G. Hensgens, L. Ye, and J. Karlsson. 2019. Systematic microbial production of optically active dissolved organic matter in subarctic lake water. Limnol. Oceanogr. 65: 951-961.

Bogard, M. J., and others. 2019. Negligible cycling of terrestrial carbon in many lakes of the arid circumpolar landscape. Nat. Geosci. 12: 180-185.

Bouchard, F., and others. 2015. Modern to millennium-old greenhouse gases emitted from ponds and lakes of the Eastern Canadian Arctic (Bylot Island, Nunavut). Biogeosciences 12: 7279-7298.

Bring, A., and others. 2016. Arctic terrestrial hydrology: A synthesis of processes, regional effects, and research challenges. J. Geophys. Res. Biogeosci 121: 621-649.

Campeau, A., and others. 2018. Stable carbon isotopes reveal soil-stream DIC linkages in contrasting headwater catchments. J. Geophys. Res. Biogeosci 123: 149-167.

Castelle, C. J., C. T. Brown, K. Anantharaman, A. J. Probst, R. H. Huang, and J. F. Banfield. 2018. Biosynthetic capacity, 
1 metabolic variety and unusual biology in the CPR and DPANN radiations. Nat. Rev. Microbiol. 16: 629-645.

Catalán, N., R. Marcé, D. N. Kothawala, and L. J. Tranvik. 2016. Organic carbon decomposition rates controlled by water retention time across inland waters. Nat. Geosci. 9: 501-504.

Centre for Northern Studies (CEN). 2018. Climate station data from Bylot Island in Nunavut, Canada, v. 1.8 (1992-2017). Nordicana: D2. doi:10.5885/45039SL-EE76C1BDAADC4890

10 Coble, P. G., S. A. Green, N. V. Blough, and R. B. Gagosian.

11 1990. Characterization of dissolved organic matter in the

12 Black Sea by fluorescence spectroscopy. Nature 348: 432-435.

Comyn-Platt, E., and others. 2018. Carbon budgets for 1.5 and $2{ }^{\circ} \mathrm{C}$ targets lowered by natural wetland and permafrost feedbacks. Nat. Geosci. 11: 568-573.

Cory, R. M., B. C. Crump, J. A. Dobkowski, and G. W. Kling. 2013. Surface exposure to sunlight stimulates $\mathrm{CO}_{2}$ release from permafrost soil carbon in the Arctic. Proc. Natl. Acad. Sci. USA 110: 3429-3434.

Cory, R. M., and G. W. Kling. 2018. Interactions between sunlight and microorganisms influence dissolved organic matter degradation along the aquatic continuum. Limnol. Oceanogr. Lett. 3: 102-116.

Cory, R. M., C. P. Ward, B. C. Crump, and G. W. Kling. 2014. Carbon cycle. Sunlight controls water column processing of carbon in arctic fresh waters. Science 345: 925-928.

Dean, J. F., J. R. van Hal, A. J. Dolman, R. Aerts, and J. T. Weedon. 2018. Filtration artefacts in bacterial community composition can affect the outcome of dissolved organic matter biolability assays. Biogeosciences 15: 7141-7154.

Drake, T. W., K. P. Wickland, R. G. Spencer, D. M. McKnight, and R. G. Striegl. 2015. Ancient low-molecular-weight organic acids in permafrost fuel rapid carbon dioxide production upon thaw. Proc. Natl. Acad. Sci. USA 112: 13946-13,951.

Elder, C. D., and others. 2018. Greenhouse gas emissions from diverse Arctic Alaskan lakes are dominated by young carbon. Nat. Clim. Chang. 8: 166-171.

Fellman, J. B., E. Hood, and R. G. M. Spencer. 2010. Fluorescence spectroscopy opens newwindows into dissolved organic matter dynamics in freshwater ecosystems: A review. Limnol. Oceanogr. 55: 2452-2462.

Forrest, A. L., B. E. Laval, R. Pieters, and D. S. S. Lim. 2008. Convectively driven transport in temperate lakes. Limnol. Oceanogr. 53: 2321-2332.

8 Fortier, D., and M. Allard. 2004. Late Holocene syngenetic icewedge polygons development, Bylot Island. Canadian Arctic Archipelagol. Can. J. Earth Sci. 41: 997-1012.

Gao, X., C. Adam Schlosser, A. Sokolov, K. W. Anthony, Q. Zhuang, and D. Kicklighter. 2013. Permafrost degradation and methane: Low risk of biogeochemical climate-warming feedback. Environ. Res. Lett. 8.
Gibson, J. A. E., W. F. Vincent, and R. Pienitz. 2001. Hydro- 55 logic control and diurnal photobleaching of CDOM in a 56 subarctic lake. Arch. Hydrobiol. 152: 143-159.

Groeneveld, M., L. Tranvik, S. Natchimuthu, and B. Koehler. 2016. Photochemical mineralisation in a boreal brown water lake: Considerable temporal variability and minor contribution to carbon dioxide production. Biogeosciences 13: 3931-3943.

Grosse, G., B. Jones, and C. Arp. 2013. Thermokarst lakes, drainage, and drained basins, p. 325-353. In J. F. Shroder, R. Giardino, and J. Harbor [eds.], Treatise on geomorphology, Vol 8, Glacial and periglacial geomorphology. San Diego, CA: Academic Press.

Guillemette, F., and P. A. del Giorgio. 2012. Simultaneous consumption and production of fluorescent dissolved organic matter by lake bacterioplankton. Environ. Microbiol. 14: 1432-1443.

Hansen, A. M., T. E. C. Kraus, B. A. Pellerin, J. A. Fleck, B. D. Downing, and B. A. Bergamaschi. 2016. Optical properties of dissolved organic matter (DOM): Effects of biological and photolytic degradation. Limnol. Oceanogr. 61: 1015-1032.

Hugelius, G., and others. 2014. Estimated stocks of circumpolar permafrost carbon with quantified uncertainty ranges and identified data gaps. Biogeosciences 11: 6573-6593.

Huguet, A., L. Vacher, S. Relexans, S. Saubusse, J. M. Froidefond, and E. Parlanti. 2009. Properties of fluorescent dissolved organic matter in the Gironde estuary. Org. Geochem. 40: 706-719.

Knoblauch, C., C. Beer, S. Liebner, M. N. Grigoriev, and E.-M. Pfeiffer. 2018. Methane production as key to the greenhouse gas budget of thawing permafrost. Nat. Clim. Chang. 8: $309-312$.

Koehler, B., T. Landelius, G. A. Weyhenmeyer, N. Machida, and L. J. Tranvik. 2014. Sunlight-induced carbon dioxide emissions from inland waters. Global Biogeochemical Cycles 28: 696-711.

Kortelainen, P., and others. 2006. Sediment respiration and lake trophic state are important predictors of large $\mathrm{CO}_{2}$ evasion from small boreal lakes. Global Change Biol. 12: 1554-1567.

Kuhry, P., and others. 2020. Lability classification of soil organic matter in the northern permafrost region. Biogeosciences 17: 361-379.

Lapierre, J. F., and P. A. del Giorgio. 2014. Partial coupling and differential regulation of biologically and photochemically labile dissolved organic carbon across boreal aquatic networks. Biogeosciences 11: 5969-5985.

Lara, M. J., and others. 2015. Polygonal tundra geomorphological change in response to warming alters future $\mathrm{CO}_{2}$ and $\mathrm{CH}_{4}$ flux on the Barrow Peninsula. Glob Chang Biol 21: 1634-1651.

Laurion, I., P. Massicotte, F. Mazoyer, K. Negandhi, and N. Mladenov. 2020. Dissolved organic matter properties and 
40 Miller, W. L., and M. A. Moran. 1997. Interaction of photo-

associated light and temperature conditions in degradation experiments with water from tundra ponds on Bylot Island, Nunavut, Canada, v. 1.0 (2010-2010). Nordicana: D56. doi: 10.5885/45618CE-5D1A86D1850841CD

Laurion, I., and N. Mladenov. 2013. Dissolved organic matter photolysis in Canadian arctic thaw ponds. Environ. Res. Lett. 8: 035026.

Laurion, I., and others. 2010. Variability in greenhouse gas emissions from permafrost thaw ponds. Limnol. Oceanogr. 55: 115-133.

Lennon, J. T., S. K. Hamilton, M. E. Muscarella, A. S. Grandy, K. Wickings, and S. E. Jones. 2013. A source of terrestrial organic carbon to investigate the browning of aquatic ecosystems. PLoS One 8: e75771. dation in warming permafrost and its influence on tundra hydrology. Nat. Geosci. 9: 312-318.

Lindell, M. J., W. Granéli, and L. J. Tranvik. 1995. Enhanced bacterial growth in response to photochemical transformation of dissolved organic matter. Limnol. Oceanogr. 40: 195-199.

Loiselle, S. A., and others. 2009. The optical characterization of chromophoric dissolved organic matter using wavelength distribution of absorption spectral slopes. Limnol. Oceanogr. 54: 590-597.

Mann, P. J., and others. 2012. Controls on the composition and lability of dissolved organic matter in Siberia's Kolyma River basin. J. Geophys. Res. Biogeosci.: 117.

Mann, P. J., and others. 2015. Utilization of ancient permafrost carbon in headwaters of Arctic fluvial networks. Nat. Commun. 6: 7856.

Martin, A. F., T. C. Lantz, and E. R. Humphreys. 2017. Ice wedge degradation and $\mathrm{CO}_{2}$ and $\mathrm{CH}_{4}$ emissions in the Tuktoyaktuk Coastlands, Northwest Territories. Arctic Sci. 4: $130-145$.

McGuire, A. D., and others. 2018. Dependence of the evolution of carbon dynamics in the northern permafrost region on the trajectory of climate change. Proc Natl Acad Sci USA 115: 3882-3887. chemical and microbial processes in the degradation of refractory dissolved organic matter from a coastal marine environment. Limnol. Oceanogr. 42: 1317-1324.

Murphy, K. R., C. A. Stedmon, D. Graeber, and R. Bro. 2013. Fluorescence spectroscopy and multi-way techniques. PARAFAC. Anal. Methods 5. 2008. Distinguishing between terrestrial and autochthonous organic matter sources in marine environments using fluorescence spectroscopy. Mar. Chem. 108: 40-58.

Negandhi, K., I. Laurion, and C. Lovejoy. 2014. Bacterial communities and greenhouse gas emissions of shallow ponds in the High Arctic. Polar Biol. 37: 1669-1683.
Negandhi, K., I. Laurion, and C. Lovejoy. 2016. Temperature (195 effects on net greenhouse gas production and bacterial 56 communities in arctic thaw ponds. FEMS Microbiol. 57 Ecol. 92.

Obernosterer, I., and R. Benner. 2004. Competition between biological and photochemical processes in the mineralization of dissolved organic carbon. Limnol. Oceanogr. 49: 117-124.

O'Reilly, C. M., and others. 2015. Rapid and highly variable warming of lake surface waters around the globe. Geophys. Res. Lett. 42: 10773-10781.

Osburn, C. L., N. J. Anderson, M. J. Leng, C. D. Barry, and E. J. Whiteford. 2019. Stable isotopes reveal independent carbon pools across an Arctic hydro-climatic gradient: Implications for the fate of carbon in warmer and drier conditions. Limnol. Oceanogr. Lett. 4: 205-213.

Poulin, B. A., J. N. Ryan, and G. R. Aiken. 2014. Effects of iron on optical properties of dissolved organic matter. Environ. Sci. Technol. 48: 10098-10106.

Rantakari, M., and P. Kortelainen. 2005. Interannual variation and climatic regulation of the $\mathrm{CO}_{2}$ emission from large boreal lakes. Glob. Chang. Biol. 11: 1368-1380.

Roth, V.-N., and others. 2019. Persistence of dissolved organic matter explained by molecular changes during its passage through soil. Nat. Geosci. 12: 755-761.

Schuur, E. A., and others. 2015. Climate change and the permafrost carbon feedback. Nature 520: 171-179.

Shirokova, L. S., and others. 2019. Humic surface waters of frozen peat bogs (permafrost zone) are highly resistant to bioand photodegradation. Biogeosciences 16: 2511-2526.

Stedmon, C. A., and R. Bro. 2008. Characterizing dissolved organic matter fluorescence with parallel factor analysis: A tutorial. Limnol. Oceanogr. Methods 6: 572-579.

Strome, D. J., and M. C. Miller. 1978. Photolytic changes in dissolved humic substances. Verh. Internat. Verein. Limnol. 20: $1248-1254$.

Stubbins, A., and others. 2017. Low photolability of yedoma permafrost dissolved organic carbon. J. Geophys. Res. Biogeosci. 122: 200-211.

Suhett, A. L., A. M. Amado, A. Enrich-Prast, F. D. A. Esteves, and V. F. Farjalla. 2007. Seasonal changes of dissolved organic carbon photo-oxidation rates in a tropical humic lagoon: The role of rainfall as a major regulator. Can. J. Fish. Aquat. Sci. 64: 1266-1272.

Surdu, C. M., C. R. Duguay, and D. Fernández Prieto. 2016. Evidence of recent changes in the ice regime of lakes in the Canadian High Arctic from spaceborne satellite observations. The Cryosphere 10: 941-960.

Tank, S. E., J. E. Vonk, M. A. Walvoord, J. W. McClelland, I. Laurion, and B. W. Abbott. 2020. Landscape matters: Predicting the biogeochemical effects of permafrost thaw on aquatic networks with a state factor approach. Permafrost Periglac. 31: 358-370. 
1 Turetsky, M. R., and others. 2020. Carbon release through abrupt permafrost thaw. Nat. Geosci. 13: 138-143.

3 Vachon, D., J.-F. Lapierre, and P. A. del Giorgio. 2016. Seasonality of photochemical dissolved organic carbon mineralization and its relative contribution to pelagic $\mathrm{CO}_{2}$ production in northern lakes. J. Geophys. Res. Biogeosci. 121: 864-878.

8 Vähätalo, A. V., K. Salonen, U. Münster, M. Järvinen, and R. G. Wetzel. 2003. Photochemical transformation of allochthonous organic matter provides bioavailable nutrients in a humic lake. Arch. Hydrobiol. 156: 287-314.

2 von Wachenfeldt, E., and L. J. Tranvik. 2008. Sedimentation in boreal lakes - the role of flocculation of allochthonousdissolved organic matter in the water column. Ecosystems 11: 803-814.

6 Vonk, J. E., and others. 2013. High biolability of ancient per17 mafrost carbon upon thaw. Geophys. Res. Lett. 40: 18 2689-2693.

19 Vonk, J. E., and others. 2015. Biodegradability of dissolved 20 organic carbon in permafrost soils and aquatic systems: A 21 meta-analysis. Biogeosciences 12: 6915-6930.

22 Ward, C. P., S. G. Nalven, B. C. Crump, G. W. Kling, and at the catchment scale. Hydrol. Earth Syst. Sci. 24: 945-966.

Wetzel, R. G., P. G. Hatcher, and T. S. Bianchi. 1995. Natural photolysis by ultraviolet irradiance of recalcitrant dissolved organic matter to simple substrates for rapidbacterial metabolism. Limnol. Oceanogr. 40: 1369-1380.

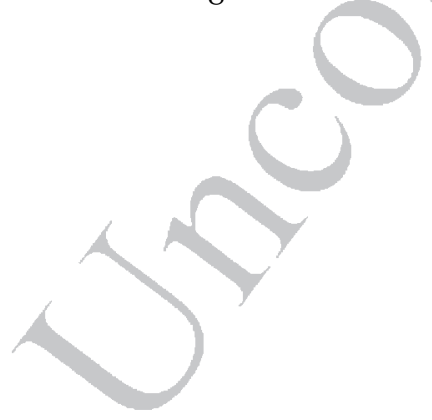

Wickland, K. P., M. P. Waldrop, G. R. Aiken, J. C. Koch, M. T. 55 Jorgenson, and R. G. Striegl. 2018. Dissolved organic car- 56 bon and nitrogen release from boreal Holocene permafrost 57 and seasonally frozen soils of Alaska. Environ. Res. Lett 13: 58 065011.

C. J., P. C. Frost, and M. A. Xenopoulos. 2013. 60 Beyond best management practices:Pelagic biogeochemical 61 dynamics in urban stormwater ponds. Ecol. Appl. 23: 62 1384-1395.

Williamson, C. E., and others. 2014. Solar ultraviolet radiation in a changing climate. Nat. Clim. Chang. 4: 434-441.

Wrona, F. J., and others. 2016. Transitions in Arctic ecosystems: Ecological implications of a changing hydrological regime. J. Geophys. Res. Biogeosci 121: 650-674.

\section{Acknowledgments}

We are grateful to L. Boutet and P. N. Bégin for their help in the field, M. Lionard and W. F. Vincent for the flow cytometer analyses, V. Preskienis for insightful discussions and his comprehensive view of the landscape, S. Prémont for his assistance at the lab, A. St-Hilaire for his help with the statistics, G. Gauthier, D. Sarrazin and the Centre for Northern Studies for their precious help with the logistics, and Parks Canada for the access to this National park. Comments and suggestions provided by two anonymous reviewers and the associate editor were substantial and greatly helped to improve the manuscript. The research was funded by the Polar Continental Shelf Program of Natural Resources Canada, the Natural Sciences and Engineering Research Council of Canada (NSERC), and Network of Centres of Excellence ArcticNet.

\section{Conflict of interest}

None declared.
Submitted 05 November 2019 Revised 19 April 2020 Accepted 19 September 2020 Associate editor: Suzanne Tank 